\title{
Off-Season Flower Induction in Mango Fruits Using Ethephon and Potassium Nitrate
}

\author{
Stephen Maloba ${ }^{1}$, Jane Ambuko ${ }^{1}$, Margaret Hutchinson ${ }^{1} \&$ Willis Owino ${ }^{2}$ \\ ${ }^{1}$ Department of Plant Science and Crop Protection, University of Nairobi, Kangemi, Nairobi, Kenya \\ ${ }^{2}$ Department of Food Science and Technology, Jomo Kenyatta University of Agriculture \& Technology, Nairobi, \\ Kenya \\ Correspondence: Jane Ambuko, Department of Plant Science and Crop Protection, University of Nairobi, P.O. \\ Box 29053-00625, Kangemi, Nairobi, Kenya. E-mail: ambuko@yahoo.com
}

Received: May 14, 2017

Accepted: July 3, 2017

Online Published: August 15, 2017

doi:10.5539/jas.v9n9p158

URL: https://doi.org/10.5539/jas.v9n9p158

This research was financed by the Regional Universities Forum for Capacity Building in Agriculture (RUFORUM).

\begin{abstract}
Seasonality in mango production is a major factor contributing to high postharvest losses reported in the value chain. Oversupply during the high season is one of the factors that contribute to the high postharvest losses $(\geq$ $50 \%$ ) in the supply chain in Kenya. Effective strategies to address seasonality can contribute significantly to postharvest loss reduction. Efficacy of two flower induction chemicals, potassium nitrate $\left(\mathrm{KNO}_{3}\right)$ and ethephon on reproductive growth parameters and yield components were evaluated on two mango varieties: 'Apple' and 'Ngowe'. $\mathrm{KNO}_{3}$ was applied at two concentrations ( 2 and 4\%), and ethephon (600 and $\left.1000 \mathrm{ppm}\right)$ then compared to control (water). They were applied to trees which failed to flower/set fruit in 2014 season. There effect was established from reproductive growth parameters: days to flowering, number of panicles per tree, fruit set per 20 panicles, fruit fall and hormonal effect. $\mathrm{KNO}_{3}(4 \%)$ and ethephon increased percentage flowering in both 'Ngowe' and 'Apple' and AEZs (Agro-Ecological Zones), significantly $(\mathrm{p}<0.05)$ shortened time to flowering and increased fruit set. The findings show that $\mathrm{KNO}_{3}$ and ethephon can be used to induce flowering/fruiting in mango fruits. These technologies can therefore be applied to induce off-season mango production to address seasonality and reduce postharvest losses during the peak season.
\end{abstract}

Keywords: apple mango, ngowe, postharvest, flowering, seasonality

\section{Introduction}

Mango is a tropical perennial fruit crop that can flower and fruit all year round. However in Kenya, mango fruiting is seasonal. In most mango producing regions of Kenya, the trees fruit only once in a year with supply peaking between October and February. As a result of seasonality, during the high season, there is often an oversupply which leads to low prices and high postharvest losses. During the peak season, the farm price ranges from 2-5 US cents per piece. A few farmers may be lucky to sell their fruits to exporters at a price of 7-10 US cents per piece (Ambuko, 2016). In Kenya the postharvest losses in the supply chain are estimated to range between $40-50 \%$, but higher figures have been cited in some studies (FAO, 2001). Most of the smallholder farmers lack appropriate post-harvest handling techniques, leading to significant losses, which affects their profits. Furthermore, these farmers do not have good storage facilities available at the farm level, and this forces them to sell their mango fruits immediately after harvest. As a result, mango supply exceeds the demand leading to wastage at the market level. Some fruits are left to rot on trees as farmer lack adequate market for them translating to huge losses to the farmers (FAO, 2003). Furthermore, seasonality has serious implications for mango processing. Seasonal production of the mangoes is only enough to supply factories for seven months of the year. Some factories are forced to close or operate below capacities during the low mango season.

This scenario in mango fruiting necessitates technologies and practices that would lead to year-round supply of mango fruits to address the problems associated with seasonality. Success has been achieved in stimulating off-season mango flowering using chemical/hormone treatments such as ethephon, paclobutrazol, calcium nitrate, 
potassium nitrate and cultural practices such as pruning (Davenport, 2009; Wilkie et al., 2008; Yeshitela et al., 2006). The phytohormone ethylene is well known to influence a number of physiological and developmental processes in plants including, but not limited to seed germination, seedling growth, and formation of the apical hook, senescence, fruit ripening, abscission and gravitropism (Abeles et al., 1992). It has been speculated that the ethylene generated when ethephon is sprayed plays a critical role in flower induction. The ethylene-generating agent, ethephon, has been used to successfully induce and increase flowering in various mango varieties in the Philippines and India (Chanda \& Pal, 1986; Dutcher, 1972). According to Dutcher (1972), Ethephon applied at 125-200 parts per million (ppm), induced flowering of 'Carabao' mango in the Philippines within six weeks after treatment. Flower induction also occurred at concentrations between 500 and 1,000 ppm. In 10-year-old 'Haden', 500-1,000 ppm ethephon applied one month before the normal flowering date increased flowering by 40-55 percent (Nunez-Elisea et al., 1980). These results were contrary to those obtained by (Pal et al., 1979), who found ethephon ineffective after five consecutive years of treatment.

Potassium nitrate $\left(\mathrm{KNO}_{3}\right)$ has been shown to stimulate early flowering and to increase numbers of panicles in trees growing in tropical and subtropical regions, thus ensuring increased and regular production (Adam, 1986). Potassium nitrate is used to induce off-season flowering and to synchronous flowering in mango. The effective spray concentration ranges from 1 to $10 \% \mathrm{KNO}_{3}$ with the optimum concentration varying with the age of the trees and climatic conditions (Kulkarni, 2004; Davenport, 2009). The mode of action for potassium nitrate during flower induction is not fully understood. In general, past studies show variability in response to flower induction chemicals such as $\mathrm{KNO}_{3}$ and ethephon as affected by various factors such as cultivars, production conditions, stage of development, dosing range, among others. To obtain reliable seasonal and off- seasonal flowering, there is need for extensive research to establish the effect of these factors on the response to the flower inducing chemicals. Therefore the objective of this study was to determine the effect of off-season flower inducing technologies (ethephon and potassium nitrate) on reproductive growth parameters and yield components of 'Apple' and 'Ngowe' mango trees grown under two different agro-ecological zones in Kenya. The first studies to demonstrate that potassium nitrate could induce flowering of mango trees were from the Philippines (Barba, 1974; Bondad \& Linsangan, 1979; Bueno \& Valmayor, 1974). Flowering was evident within seven days after treatment and was effective on shoots that were between 4.5 and 8.5 months old when treated. Concentrations of potassium nitrate between $1 \%$ and $8 \%$ stimulated flowering of seedling 'Carabao' and 'Pahutan' trees and 'Pico' trees within one week after sprays were applied (Bondad \& Linsangan, 1979). The treatment was effective for stimulating flowering of trees that had remained vegetative well beyond normal bearing ages, for advancing the flowering and fruiting periods, and for breaking the biennial bearing habits of trees. Potassium nitrate is currently recommended in the Philippines for inducing uniform flowering and for the production of off-season fruits in the 'Pico' and 'Carabao' cultivars (Madamba, 1978). In India, workers have reported variable results with potassium nitrate (Pal et al., 1979). Areas that have reported success with potassium nitrate include Trinidad with 'Tommy Atkins' (James et al., 1992), the Ivory Coast with 'Kent' and 'ZiU' (Goguey, 1992) and Mexico with 'Manila' and 'Haden' (Nunez-Elisea, 1985). In studies conducted in Hawaii, potassium nitrate application to mature 'Haden' trees in Pahala and Waimanalo also showed that flowering was stimulated in October and November. Stimulation of flowering during these periods could enable producers to obtain fruits five months later (April), which would be about two months earlier than the usual seasonal production in Hawaii. Preliminary tests with other varieties showed that 'Fairchild' was not as responsive as 'Haden' to applications made in November, while no response was observed with 'Keitt' (Hamilton et al., 1992).

Ethephon has been successful in India for increasing flowering of 'Langra and 'Deshehari' during "off years" (Chacko et al., 1972, 1974; Chanda \& Pal, 1986) and for inducing earlier production in juvenile plants (Chacko et al., 1974). Some past studies show variability in responses to ethephon treatments. In 10-year-old 'Haden', 500-1,000 parts per million applied one month before the normal flowering date increased flowering by 40-55 percent (Nunez-Elisea et al., 1980). These results were contrary to those obtained by (Pal et al., 1979), who found ethephon ineffective after five consecutive years of treatment, and by (Sen et al., 1973) who reported an increase in flowering during "on" years but failed to stimulate flowering during "off” years.

Efficacy of flower inducing chemicals is dependent on several factors including mango variety, dosing, time of application and stage of development among others (Galan \& Fernandez, 1987). In some cases, poor timing or wrong dosage in the use of flower inducers has achieved the opposite effect, often inhibiting flowering or reducing the flowering percentage in the subsequent season.

Tropical climates are conducive to year-round vegetative growth of perennial tropical fruit crops, but flowering and fruit set are usually seasonal. Flowering from one season to the next is unreliable, because the environmental signals for flower initiation are often inconsistent, subtle, or poorly defined. An alternative to dependence upon 
environmental signals for flower initiation is the development of management strategies that can substitute for these signals (Dutcher, 1972). In Hawaii, one method to extend the availability of fruit within or slightly beyond the ripening period of May-June to September is by growing different cultivars. There are usually some seedling and off-season fruits available at other times. Recently, technologies have been developed to induce flowering of mangoes during off-seasons (Hamilton et al., 1992). The use of off-season flower induction technologies has been commercially accepted. This is because of the benefits of these technologies which include an altered earlier harvest, to take advantage of the good market price. Also, these technologies help to fill the gap of under-supply and reduce effect of disease on the crop since flowering is induced during the dry spell. The readiness of a tree to flower is an important factor for a successful operation. To use chemical treatments effectively to control mango fruit production, application should be assessed in relationship to the plant's growth phenology (Macias-Gonzales et al., 1992).

The aim of this study was to establish the effect of ethephon and potassium nitrate application on flowering of two mango varieties (Apple and Ngowe) grown in two contrasting agro-ecological zones (Embu and Makueni Counties). Effect of the treatments was established from reproductive growth parameters including days to $50 \%$ flowering, number of panicles per tree, average fruit set per 20 panicles and total number of fruits per tree. Other responses of the trees to the treatments such as fruit fall and hormonal effect (internal ethylene in young fruits) were also evaluated.

\section{Materials and Methods}

\subsection{Study Sites}

The study was conducted in two agro-ecological zones (AEZs) of Kenya namely Embu County (a high potential mango production AEZ-V) and Makueni County (a low potential mango production AEZ-III). Embu County is a semi-humid region with a mean annual temperature ranging between $12-27^{\circ} \mathrm{C}$. The rainfall pattern is generally bimodal with two distinct rainy seasons. The average annual rainfall in Embu ranges between $700 \mathrm{~mm}$ and 1300 $\mathrm{mm}$. Makueni County is a semi-arid area found in agro-ecological zone $\mathrm{V}$ where the annual rainfall ranges between $150 \mathrm{~mm}$ to $650 \mathrm{~mm}$ and the temperatures between $21^{\circ} \mathrm{C}$ to $35^{\circ} \mathrm{C}$.

\subsection{Research Design and Treatments}

Two flower induction chemicals, potassium nitrate $\left(\mathrm{KNO}_{3}\right)$ and Ethephon were evaluated in commercial farms in Embu and Makueni Counties. Test trees comprised of randomly selected 'Apple' and 'Ngowe' mango trees. The trees were of similar size and vigor with an average age of 6 to 8 years. Potassium nitrate was applied at two concentrations ( 2 and $4 \%$ ), while ethephon was applied at 600 and $1000 \mathrm{ppm}$. These treatments were compared to a control (water). The treatments were applied to mango trees which failed to flower/set fruit in the 2014 season. Prior to spraying, 100 terminal shoots were marked randomly on each tree for percentage flowering determination. After inflorescence development, 20 panicles per tree were marked randomly on each tree to establish fruit set. The experiment was laid out in a randomized complete design with three replicates and three trees per treatment where the three test trees represented a replicate. Each replicate comprised of fifteen trees.

\subsection{Data Collection}

Effect of the treatments was established from reproductive growth parameters including days to flowering, percentage flowering and average fruit set per 20 panicles. Total number of fruits per tree was also determined. Other responses of the trees to the treatments such as fruit fall and hormonal effect (internal ethylene in young fruits) were also evaluated. Days to $50 \%$ flowering was recorded as the number of days between the spray and the stage where inflorescences per tree were at bud break. Percentage flowering was established from the hundred tagged shoots and the $\%$ of the tagged shoots that flowered was recorded per test tree at the $50 \%$ flowering stage. The fruit set was evaluated at the pea size stage (when the immature fruits were at the size of a pea).The number of immature fruits was counted on 20 panicles which were marked randomly on the test trees. The base of each test tree was cleared a week from initial fruit set and then fruit drop monitored from the fruits that were collected under the tree every day. The cumulative fruit drop values were compiled and analyzed after every two weeks and expressed as a percentage of the initial fruit set.

\subsubsection{Ethylene Production Rate Measured}

Lab analysis of internal ethylene in the young fruits commenced after one month from fruit set. Ten young fruits were uniformly peeled and each placed in plastic jars of $700 \mathrm{ml}$ whose covers were fitted with a self-sealing rubber septum for gas sampling. The fruits were then incubated for two hours at room temperature $25^{\circ} \mathrm{C}$. Gas samples from the headspace gas were taken using an airtight $1 \mathrm{ml}$ hypodermic syringe and injected into gas 
chromatographs (Model GC-9A, Shimadzu Corp., Kyoto, Japan for ethylene production rate). Ethylene production rate was expressed as $\mathrm{nl} / \mathrm{g} / \mathrm{hr}$. (Ouma, 2014).

\subsubsection{Harvesting}

Any harvesting done from the three test trees for each treatment and the control was recorded from the onset of harvesting up to the end of the harvesting season. The total number of fruits in each harvest per tree for each treatment was then determined.

\subsection{Data Analysis}

Analysis of Variance (ANOVA) was done using GENSTAT ( $15^{\text {th }}$ edition). Treatment means were separated using the Least Significant Difference (LSD) at the 5\% level of significance.

\section{Results}

3.1 Effect of Potassium Nitrate $\left(\mathrm{KNO}_{3}\right)$ and Ethephon on the Number of Days to 50\% Flowering of 'Apple' and 'Ngowe' Mango Trees in Embu and Makueni Counties

Application of $\mathrm{KNO}_{3}$ and Ethephon significantly $(\mathrm{p}<0.05)$ shortened the time to flowering regardless of production location or variety. For both treatments, higher concentrations, $4 \%$ and $1000 \mathrm{ppm}$ (of $\mathrm{KNO}_{3}$ and Ethephon respectively) almost halved the number of days to $50 \%$ flowering. The treatment effect was affected by the AEZ and variety. In Embu, 'Apple' fruits treated with $4 \% \mathrm{KNO}_{3}$ and $1000 \mathrm{ppm}$ of Ethephon attained 50\% flowering 39 and 36 earlier (respectively) compared to the untreated control. In Makueni, $4 \% \mathrm{KNO}_{3}$ and $1000 \mathrm{ppm}$ treatment reduced the number of days to $50 \%$ flowering by 63 and 58 days respectively compared to the untreated control. 'Ngowe' fruits were more responsive than 'Apple' with $4 \% \mathrm{KNO}_{3}$ and $1000 \mathrm{ppm}$ of Ethephon resulting in 42 and 37 days earlier flowering compared to the untreated control in Embu while in Makueni the treated fruits flowered 44 and 48 days earlier than the untreated control (Table 1).

Table 1. Effect of Potassium nitrate $\left(\mathrm{KNO}_{3}\right)$ and Ethephon on the number of days to $50 \%$ flowering of 'Apple' and 'Ngowe' mango trees in Embu and Makueni Counties

\begin{tabular}{|c|c|c|c|c|c|}
\hline \multirow{3}{*}{ Variety/Treatment } & \multicolumn{4}{|c|}{ Production Location } & \multirow{3}{*}{ Means } \\
\hline & \multicolumn{2}{|c|}{ Embu } & \multicolumn{2}{|c|}{ Makueni } & \\
\hline & 'Apple' & 'Ngowe' & 'Apple' & 'Ngowe' & \\
\hline $2 \% \mathrm{KNO}_{3}$ & $101.0( \pm 4.6) \mathrm{h}$ & $97.3( \pm 3.1) \mathrm{gh}$ & $77.0( \pm 3.6) \mathrm{d}$ & $74.0( \pm 1.7) \mathrm{d}$ & 87.3 \\
\hline $4 \% \mathrm{KNO}_{3}$ & $90.0( \pm 3.0) \mathrm{f}$ & $83.0( \pm 1.7) \mathrm{e}$ & $50.0( \pm 6.0) \mathrm{a}$ & $45.0( \pm 5.0) \mathrm{a}$ & 67.0 \\
\hline Ethephon 600 ppm & $103.0( \pm 2.6) \mathrm{h}$ & $100.0( \pm 5.6) \mathrm{h}$ & $59.0( \pm 2.6) \mathrm{c}$ & $57.0( \pm 3.0) \mathrm{c}$ & 79.8 \\
\hline Ethephon 1000 ppm & $93.0( \pm 3.0) \mathrm{fg}$ & $88.0( \pm 2.0) \mathrm{ef}$ & $55.0( \pm 3.0) b c$ & $51.0( \pm 5.3) \mathrm{b}$ & 71.8 \\
\hline Control & $129.0( \pm 4.6) \mathrm{j}$ & $125.0( \pm 3.6) \mathrm{j}$ & $113.0( \pm 3.0) \mathrm{i}$ & $99.3( \pm 2.1) \mathrm{h}$ & 116.6 \\
\hline $\mathrm{LSD}_{0.05}$ (Treat) & 7.5 & 3.8 & 6.5 & 3.9 & \\
\hline LSD $_{0.05}($ Loc. $\times$ Var. $\times$ Treat $)$ & 5.2 & & & & \\
\hline CV $(\%)$ & 3.7 & & & & \\
\hline
\end{tabular}

Note. Values followed by the same letter(s) in a column or a row do not differ significantly at $5 \%$ level of significance. Loc $=$ location, Var $=$ variety, and Treat $=$ treatment.

\subsection{Effect of Potassium Nitrate $\left(\mathrm{KNO}_{3}\right)$ and Ethephon on Percentage Flowering of 'Apple' and 'Ngowe' Mango Trees in Embu and Makueni Counties}

Application of $\mathrm{KNO}_{3}$ and Ethephon significantly $(\mathrm{p}<0.05)$ increased percentage flowering $(\%$ of tagged shoots that flowered at 50\% tree flowering) in both 'Ngowe' and 'Apple' in both AEZs. Response to ethephon increased with concentration. $1000 \mathrm{ppm}$ gave the best response. The treatment effect was affected by the AEZ and variety. In Embu, 'Apple' fruits treated with $4 \% \mathrm{KNO}_{3}$ and $1000 \mathrm{ppm}$ of Ethephon had $22 \%$ and $16 \%$ (respectively) flowering higher compared to the untreated control. In Makueni, $4 \% \mathrm{KNO}_{3}$ and $1000 \mathrm{ppm}$ treatment had $94 \%$ and $95 \%$ flowering compared to $25 \%$ for the untreated control. In 'Ngowe' fruits, $4 \% \mathrm{KNO}_{3}$ and $1000 \mathrm{ppm}$ of Ethephon induced $40 \%$ and $29 \%$ more flowering compared to the untreated control in Embu while in Makueni $68.7 \%$ and $69 \%$ more flowering were recorded for the same treatments than the untreated control (Table 2). 
Table 2. Effect of Potassium nitrate $\left(\mathrm{KNO}_{3}\right)$ and Ethephon on percentage flowering of 'Apple' and 'Ngowe' mango trees in Embu and Makueni Counties

\begin{tabular}{|c|c|c|c|c|c|}
\hline \multirow{3}{*}{ Variety/Treatment } & \multicolumn{4}{|c|}{ Production Location } & \multirow{3}{*}{ Means } \\
\hline & \multicolumn{2}{|c|}{ Embu } & \multicolumn{2}{|c|}{ Makueni } & \\
\hline & 'Apple' & 'Ngowe' & 'Apple’ & 'Ngowe' & \\
\hline $2 \% \mathrm{KNO}_{3}$ & $10.0( \pm 2.6) \mathrm{b}$ & $19.0( \pm 4.6) \mathrm{c}$ & $38.0( \pm 5.6) \mathrm{g}$ & $43.0( \pm 2.6) \mathrm{h}$ & 27.5 \\
\hline $4 \% \mathrm{KNO}_{3}$ & $27.0( \pm 4.0) \mathrm{ef}$ & $48.0( \pm 3.0) \mathrm{i}$ & $94.0( \pm 3.0) \mathrm{k}$ & $99.71( \pm 0.6) \mathrm{m}$ & 67.2 \\
\hline Ethephon 600 ppm & $11.0( \pm 3.0) \mathrm{b}$ & $18.0( \pm 4.6) \mathrm{c}$ & $52.0( \pm 2.0) \mathrm{i}$ & $72.0( \pm 3.0) \mathrm{j}$ & 38.3 \\
\hline Ethephon 1000 ppm & $21.0( \pm 2.0) \mathrm{cd}$ & $37.0( \pm 3.0) \mathrm{g}$ & $95.0( \pm 5.0) \mathrm{kl}$ & $100.0( \pm 0.0) \mathrm{m}$ & 63.3 \\
\hline Control & $5.0( \pm 2.0) \mathrm{a}$ & $8.0( \pm 2.6) \mathrm{ab}$ & $25.0( \pm 2.0) \mathrm{de}$ & $31.0( \pm 6.0) \mathrm{f}$ & 17.3 \\
\hline $\mathrm{LSD}_{0.05}$ (Treat) & 4.4 & 4.1 & 7.7 & 6.4 & \\
\hline $\mathrm{LSD}_{0.05}($ Loc. $\times$ Var. $\times$ Treat $)$ & 4.8 & & & & \\
\hline $\mathrm{CV}(\%)$ & 6.8 & & & & \\
\hline
\end{tabular}

Note. Values followed by the same letter(s) in a column or a row do not differ significantly at $5 \%$ level of significance. Loc $=$ location, Var $=$ variety, and Treat $=$ treatment.

\subsection{Effect of Potassium Nitrate $\left(\mathrm{KNO}_{3}\right)$ and Ethephon on Fruit Set of 'Apple' and 'Ngowe' Mango Trees in Embu and Makueni Counties}

Application of $\mathrm{KNO}_{3}$ and Ethephon significantly $(\mathrm{p}<0.05)$ increased fruit set in both 'Ngowe' and 'Apple' with $4 \% \mathrm{KNO}_{3}$ and $1000 \mathrm{ppm}$ of Ethephon resulting in the highest fruit set in both AEZs and varieties. The treatment effect was affected by the AEZ and variety. In Embu, 'Apple' fruits treated with $4 \% \mathrm{KNO}_{3}$ and $1000 \mathrm{ppm}$ of Ethephon had 216 and 152 fruits (respectively) compared to 31 for the untreated control. $\mathrm{KNO}_{3}$ at $2 \%$ and 600 ppm of Ethephon recorded 25 and 52 immature fruits more compared to the untreated control. In Makueni, $\mathrm{KNO}_{3}$ and 1000 ppm treatment increased fruit set by 198 and 103 fruits respectively compared to the untreated control. In 'Ngowe' fruits treated with $4 \% \mathrm{KNO}_{3}$ and $1000 \mathrm{ppm}$ had an increase of 227 and 197 fruits respectively compared to the untreated control in Embu while in Makueni 233 and 126 more fruits at the pea size stage were counted compared to the untreated control (Table 3).

Table 3. Effect of Potassium nitrate $\left(\mathrm{KNO}_{3}\right)$ and Ethephon on fruit set of 'Apple' and 'Ngowe' mango trees in Embu and Makueni Counties

\begin{tabular}{|c|c|c|c|c|c|}
\hline \multirow{3}{*}{ Variety/Treatment } & \multicolumn{4}{|c|}{ Production Location } & \multirow{3}{*}{ Means } \\
\hline & \multicolumn{2}{|c|}{ Embu } & \multicolumn{2}{|c|}{ Makueni } & \\
\hline & 'Apple' & 'Ngowe' & 'Apple' & 'Ngowe' & \\
\hline $2 \% \mathrm{KNO}_{3}$ & $56.7( \pm 5.8) \mathrm{c}$ & $110.3( \pm 6.2) \mathrm{e}$ & $139.5( \pm 3.9) \mathrm{g}$ & $169.0( \pm 4.0) \mathrm{i}$ & 118.9 \\
\hline $4 \% \mathrm{KNO}_{3}$ & $216.0( \pm 2.6) \mathrm{k}$ & $280.8( \pm 3.7) \mathrm{m}$ & $237.0( \pm 2.6) 1$ & $288.0( \pm 4.4) n$ & 255.5 \\
\hline Ethephon 600ppm & $83.3( \pm 3.2) \mathrm{d}$ & $130.0( \pm 7.1) \mathrm{f}$ & $113.0( \pm 2.0) \mathrm{e}$ & $134.6( \pm 0.8) \mathrm{fg}$ & 115.2 \\
\hline Ethephon 1000ppm & $152.6( \pm 5.0) \mathrm{h}$ & $250.0( \pm 4.3) \mathrm{m}$ & $141.6( \pm 6.1) \mathrm{g}$ & $181.0( \pm 3.6) \mathrm{j}$ & 181.3 \\
\hline Control & $31.0( \pm 2.0) \mathrm{a}$ & $53.0( \pm 8.5) \mathrm{c}$ & $39.0( \pm 3.0) \mathrm{b}$ & $55.0( \pm 2.0) \mathrm{g}$ & 44.5 \\
\hline $\mathrm{LSD}_{0.05}$ (Treat) & 7.1 & 4.1 & 7.6 & 4.0 & \\
\hline $\mathrm{LSD}_{0.05}($ Loc. $\times$ Var. $\times$ Treat $)$ & 7.2 & & & & \\
\hline CV $(\%)$ & 3.1 & & & & \\
\hline
\end{tabular}

Note. Values followed by the same letter(s) in a column or a row do not differ significantly at $5 \%$ level of significance. $\operatorname{Loc}=$ location, Var $=$ variety, and Treat $=$ treatment.

\subsection{Effect of Ethephon on Internal Ethylene ( $\mathrm{nl} / \mathrm{g} / \mathrm{hr}$.) in 'Apple' and 'Ngowe' Immature Fruits Sampled 44 Days from Fruit Set from Embu and Makueni Counties}

Application of Ethephon significantly $(\mathrm{p}<0.05)$ increased ethylene levels in the immature fruits after six weeks from fruit set in both 'Ngowe' and 'Apple'. The treatment effect was affected by the AEZ and variety. In Embu, 'Apple' fruits treated with $1000 \mathrm{ppm}$ of Ethephon had $1.3 \mathrm{nl} / \mathrm{g} / \mathrm{hr}$. less than treated 'Apple' from Makueni while fruits from the untreated control had $3.3 \mathrm{nl} / \mathrm{g} / \mathrm{hr}$. and $4.2 \mathrm{nl} / \mathrm{g} / \mathrm{hr}$. in the two locations (respectively). In 'Ngowe' ethylene content for fruits from treated trees varied significantly $(\mathrm{p}<0.05)$ between the two locations. The content 
was $3.1 \mathrm{nl} / \mathrm{g} / \mathrm{hr}$. and $4.9 \mathrm{nl} / \mathrm{g} / \mathrm{hr}$. for Embu and Makueni respectively. Significant $(\mathrm{p}<0.05)$ differences occurred between varieties. 'Ngowe' in Makueni produced $1.6 \mathrm{nl} / \mathrm{g} / \mathrm{hr}$. more than 'Apple' in Embu (Table 4).

Table 4. Effect of Ethephon on internal ethylene (nl/g/hr.) in 'Apple' and 'Ngowe' immature fruits sampled 44 days from fruit set from Embu and Makueni Counties

\begin{tabular}{|c|c|c|c|c|c|}
\hline \multirow{3}{*}{ Variety/Treatment } & \multicolumn{4}{|c|}{ Production Location } & \multirow{3}{*}{ Means } \\
\hline & \multicolumn{2}{|c|}{ Embu } & \multicolumn{2}{|c|}{ Makueni } & \\
\hline & 'Apple' & 'Ngowe' & 'Apple' & 'Ngowe' & \\
\hline Ethephon 1000 ppm & $3.2( \pm 0.1) \mathrm{a}$ & $3.1( \pm 0.1) \mathrm{a}$ & $4.5( \pm 0.5) b$ & $4.9( \pm 0.8) b$ & 3.9 \\
\hline Control & $3.3( \pm 0.1) \mathrm{a}$ & $3.1( \pm 0.1) \mathrm{a}$ & $4.2( \pm 0.2) b$ & $4.3( \pm 0.4) b$ & 3.7 \\
\hline $\mathrm{LSD}_{0.05}$ (Treat) & 0.3 & 0.3 & 0.7 & 1.5 & \\
\hline $\operatorname{LSD}_{0.05}($ Loc. $\times$ Var. $\times$ Treat $)$ & 0.6 & & & & \\
\hline CV $(\%)$ & 8.5 & & & & \\
\hline
\end{tabular}

Note. Values followed by the same letter(s) in a column or a row do not differ significantly at 5\% level of significance. Loc $=$ location, $\operatorname{Var}=$ variety, and Treat $=$ treatment.

\subsection{Effect of Potassium Nitrate $\left(\mathrm{KNO}_{3}\right)$ and Ethephon on Percentage Fruit Drop after 14 Days from Fruit Set for 'Apple' and 'Ngowe' Mango Trees in Embu and Makueni Counties}

Application of $\mathrm{KNO}_{3}$ and Ethephon significantly $(\mathrm{p}<0.05)$ increased percentage fruit drop after two weeks from fruit set of the test trees in both AEZs and varieties. The treatment effect was affected by the AEZ and variety. In Embu, 4\% $\mathrm{KNO}_{3}$ and $1000 \mathrm{ppm}$ of Ethephon reduced and increased fruit fall by 1.8 and $16.2 \%$ respectively compared to the untreated control in 'Apple' fruits. Trees treated with $4 \% \mathrm{KNO}_{3}$ had the highest fruit retention ( $10.5 \%$ fruit fall). In Makueni, $4 \% \mathrm{KNO}_{3}$ and $1000 \mathrm{ppm}$ treatment reduced and increased fruit fall by 1.8 and $16.2 \%$ respectively compared to the untreated control. In 'Ngowe' $4 \% \mathrm{KNO}_{3}$ almost halved the percentage fruit fall while 1000ppm of Ethephon increased fruit fall by $8.1 \%$ in Embu. In Makueni, the same treatments recorded 25.2 and $53.9 \%$ fruit fall compared to $29.4 \%$ for the untreated control (Table 5).

Table 5. Effect of Potassium nitrate $\left(\mathrm{KNO}_{3}\right)$ and Ethephon on percentage fruit drop after 14 days from fruit set for 'Apple' and 'Ngowe' mango trees in Embu and Makueni Counties

\begin{tabular}{|c|c|c|c|c|c|}
\hline \multirow{3}{*}{ Variety/Treatment } & \multicolumn{4}{|c|}{ Production Location } & \multirow{3}{*}{ Means } \\
\hline & \multicolumn{2}{|c|}{ Embu } & \multicolumn{2}{|c|}{ Makueni } & \\
\hline & 'Apple' & 'Ngowe' & 'Apple' & 'Ngowe' & \\
\hline $2 \% \mathrm{KNO}_{3}$ & $11.7( \pm 2.1) \mathrm{a}$ & 14.5( \pm 3.4$) \mathrm{abc}$ & $21.7( \pm 8.2) \mathrm{d}$ & $30.8( \pm 1.8)$ efg & 19.7 \\
\hline $4 \% \mathrm{KNO}_{3}$ & $10.5( \pm 2.4) \mathrm{a}$ & $13.0( \pm 2.0) \mathrm{ab}$ & $18.7( \pm 3.2) \mathrm{bcd}$ & $25.2( \pm 4.1) \mathrm{de}$ & 16.9 \\
\hline Ethephon 600 ppm & $14.0( \pm 3.0) \mathrm{abc}$ & $19.6( \pm 1.0) \mathrm{bcd}$ & $24.3( \pm 3.9) \mathrm{de}$ & $38.0( \pm 8.9) \mathrm{h}$ & 24.0 \\
\hline Ethephon 1000 ppm & $20.5( \pm 3.4) \mathrm{cd}$ & $33.5( \pm 2.0) \mathrm{fgh}$ & $36.7( \pm 3.2) \mathrm{gh}$ & $53.9( \pm 3.0) \mathrm{i}$ & 36.2 \\
\hline Control & $11.7( \pm 2.2) \mathrm{a}$ & $25.4( \pm 4.6) \mathrm{de}$ & $20.5( \pm 2.5) \mathrm{cd}$ & $29.4( \pm 0.9) \mathrm{ef}$ & 21.8 \\
\hline $\mathrm{LSD}_{0.05}$ (Treat) & 4.8 & 5.9 & 7.9 & 9.0 & \\
\hline $\mathrm{LSD}_{0.05}($ Loc. $\times$ Var. $\times$ Treat $)$ & 6.2 & & & & \\
\hline CV $(\%)$ & 15.7 & & & & \\
\hline
\end{tabular}

Note. Values followed by the same letter(s) in a column or a row do not differ significantly at 5\% level of significance. Loc $=$ location, $\operatorname{Var}=$ variety, and Treat $=$ treatment.

3.6 Effect of Potassium Nitrate $\left(\mathrm{KNO}_{3}\right)$ and Ethephon on Total Number of 'Apple' and 'Ngowe' Fruits per Tree in Embu and Makueni Counties

Application of $\mathrm{KNO}_{3}$ and Ethephon significantly $(\mathrm{p}<0.05)$ increased total number of fruits per tree in both 'Ngowe' and 'Apple' with $4 \% \mathrm{KNO}_{3}$ resulting in the highest total number of fruits in both AEZs and varieties on average though no clear trend occurred. The treatment effect was affected by the AEZ and variety. In Embu, 'Apple' fruits treated with $4 \% \mathrm{KNO}_{3}$ and $1000 \mathrm{ppm}$ of Ethephon yielded 140 and 79 fruits respectively compared to 149 fruits from the untreated control. In Makueni, $4 \% \mathrm{KNO}_{3}$ and $1000 \mathrm{ppm}$ treatment increased total number of 
fruits per tree by 35 and 7 fruits (respectively). 'Ngowe' fruits were more responsive than 'Apple' in Embu unlike the case was in Makueni. 4\% $\mathrm{KNO}_{3}$ and $1000 \mathrm{ppm}$ of Ethephon resulted in 86 and 19 more 'Ngowe' fruits respectively compared to the untreated control in Embu while in Makueni the same treatment had 14 and 9 fruits less than the untreated control (Table 6).

Table 6. Effect of Potassium nitrate $\left(\mathrm{KNO}_{3}\right)$ and Ethephon on total number of 'Apple' and 'Ngowe' fruits per tree in Embu and Makueni Counties

\begin{tabular}{|c|c|c|c|c|c|}
\hline \multirow{3}{*}{ Variety/Treatment } & \multicolumn{4}{|c|}{ Production Location } & \multirow{3}{*}{ Means } \\
\hline & \multicolumn{2}{|c|}{ Embu } & \multicolumn{2}{|c|}{ Makueni } & \\
\hline & 'Apple' & 'Ngowe' & 'Apple' & 'Ngowe' & \\
\hline $2 \% \mathrm{KNO}_{3}$ & $110.3( \pm 4.5) b$ & $185.7( \pm 6.0) \mathrm{i}$ & $235.7( \pm 3.0) \mathrm{k}$ & $77.7( \pm 9.0) \mathrm{a}$ & 152.4 \\
\hline $4 \% \mathrm{KNO}_{3}$ & $140.7( \pm 6.0) \mathrm{e}$ & $217.3( \pm 2.5) \mathrm{j}$ & $292.0( \pm 10.0) 1$ & $107.3( \pm 9.5) b$ & 189.3 \\
\hline Ethephon 600 ppm & $111.3( \pm 3.5) b$ & $172.3( \pm 7.5) \mathrm{h}$ & $185.0( \pm 15.0) \mathrm{i}$ & $84.3( \pm 9.5) \mathrm{a}$ & 138.2 \\
\hline Ethephon 1000 ppm & $79.0( \pm 5.0) \mathrm{a}$ & $150.3( \pm 4.5) \mathrm{f}$ & $157.7( \pm 19.0) \mathrm{g}$ & $112.7( \pm 14.0) b$ & 124.9 \\
\hline Control & $149.3( \pm 3.5) \mathrm{f}$ & $131.3( \pm 3.5) \mathrm{d}$ & $150.3( \pm 7.5) \mathrm{f}$ & $121.7( \pm 9.0) \mathrm{c}$ & 138.2 \\
\hline $\mathrm{LSD}_{0.05}$ (Treat) & 2.0 & 3.8 & 11.8 & 4.0 & \\
\hline $\mathrm{LSD}_{0.05}($ Loc. $\times$ Var. $\times$ Treat $)$ & 7.3 & & & & \\
\hline CV $(\%)$ & 3.0 & & & & \\
\hline
\end{tabular}

Note. Values followed by the same letter(s) in a column or a row do not differ significantly at 5\% level of significance. $\operatorname{Loc}=$ location, Var $=$ variety, and Treat $=$ treatment.

\section{Discussion}

Understanding mango flowering is essential to efficiently utilize management systems that extend the flowering and crop production seasons (Kulkarni, 2004; Davenport, 2009). Flower induction in mango is the temporary commitment of buds to evoke a particular development pathway which can be a vegetative shoot, generative shoot or mixed shoot when growth is initiated. Initiation of plant flowering refers to the onset of floral bud growth in actively growing vegetative shoots after the floral inductive event (Huala \& Sussex, 1993; Kinet, 1993).

In the present study flower induction chemicals (potassium nitrate and ethephon) were used to manipulate flowering in trees that failed to flower during the fruiting season. The findings show that the treatments had a significant effect on reproductive growth parameters and subsequently on the yield components of the fruit trees. The effect of the chemicals was significantly affected by the mango variety and production location. There was significant interaction amongst the treatments, mango production location and the varieties. The differences in responses observed could be attributed to many factors. One of the major differences in response was observed between the two AEZs-Makueni and Embu. The two AEZ differ significantly in temperature and rainfall. Embu is relatively cooler (mean temperature $19^{\circ} \mathrm{C}$ ) while Makueni is hotter (mean annual temperature ranging between 26 ${ }^{\circ} \mathrm{C}$ to $35^{\circ} \mathrm{C}$ ). The significant differences in temperature, coupled with differences in rainfall and soils could have significant effect on tree growth and physiology, subsequently affecting the trees' responses to treatments (Ouma, 2014).

Significant $\mathrm{KNO}_{3}$ treatment effect on time to flowering, percentage flowering, number of panicles and fruit set was observed in both mango varieties regardless of the production location. $\mathrm{KNO}_{3}$ at $4 \%$ induced early flowering in treated trees compared to control trees. This effect could be in part attributed to additional $\mathrm{N}$ from $\mathrm{KNO}_{3}$. Increased nitrogen fertilization through the soil has been found to increase fruit retention and yield in mango (Smith, 1994; Yeshitela et al., 2004). According to Kulkarni (2014), the floral stimulus is present in stems when buds are forced in response to $\mathrm{KNO}_{3}$ and that $\mathrm{KNO}_{3}$ may sensitize buds to the floral stimulus. Davenport (2003), observed $100 \%$ vegetative shoots when $4 \% \mathrm{KNO}_{3}$ foliar was applied to two-month-old stems whereas, application of the same spray treatment to 4.5 -month-old stems on trees in the orchards resulted in $100 \%$ reproductive shoots. The study shows that amongst other factors, the time of application of the flower induction chemical has a significant effect on the kind of response obtained. In the present study, the response was also affected by the concentration of the chemicals with $4 \%$ and $1,000 \mathrm{ppm}$ of $\mathrm{KNO}_{3}$ and ethephon respectively resulting in the greatest response. Similar results were reported by Sergent et al. (1996) who observed that trees treated with high $\mathrm{KNO}_{3}$ dose (3.6 and $\left.4.6 \%\right)$ induced early flowering and harvesting (30 to 45 days earlier) as compared to those treated with lower concentrations and untreated trees. Similarly, higher concentration of Ethephon (600 ppm and 1000 ppm) induced 
higher percentage flowering and fruit set. The ethylene-generating agent, Ethephon, has been used to successfully induce and increase flowering in various mango varieties in the Philippines and India (Chanda \& Pal, 1986; Dutcher, 1972). The phytohormone ethylene is well known to influence a number of physiological and developmental processes in plants including seed germination, seedling growth, and formation of the apical hook, senescence, fruit ripening, abscission and gravitropism (Abeles et al., 1992). In the present study, the response to Ethephon increased with concentration. This observation concurs with the findings of Galan and Fernandez (1987) who reported clear different results for 400 and $800 \mathrm{ppm}$ ethephon rates applied to three mango cultivars (Zill, Haden and Sensation). In this study epinasty of mature leaves, senescence of some leaves, flowers and some fruit abscission was observed in ethephon treated trees. Epinasty indirectly associates to the sign of exposure of plant tissues to ethylene. More effect was observed in test trees treated with $1000 \mathrm{ppm}$ ethephon in both locations. In a previous study, very high percentage abscission was reported in fruit trees treated with ethephon at $800 \mathrm{ppm}$ or more and partial results in trees treated with $400 \mathrm{ppm}$ (Stephenson \& Gallagher, 1978). The effect of ethylene on abscission can be attributed to ethylene emitted with the decomposition of ethephon. The effect may be explained by the well-known action of ethylene in promoting senescence and death of flowers (Abeles, 1973). These observations indirectly link to symptoms of ethylene production and indicate the involvement of endogenous ethylene in flowering. Other related studies show that $\mathrm{KNO}_{3}$-stimulated flowering of mango is mediated by increased levels of endogenous ethylene. Mosqueda-Vazquez and Avila-Resendiz (1985) reported that the efficacy of $\mathrm{KNO}_{3}$ was negated by cobalt chloride $\left(\mathrm{CoCl}_{2}\right)$ and silver nitrate $\left(\mathrm{AgNO}_{3}\right)$ which inhibit the synthesis and action of ethylene, respectively, when sprayed $1-4 \mathrm{~h}$ after $\mathrm{KNO}_{3}$. In that study, a gradual increase in endogenous leaf ethylene production was reported as the season of floral initiation approached. Ethylene production by stems producing reproductive shoots was up to fivefold that of resting stems. According to Davenport and Nunez-Elisea (1990), elevated ethylene production occurred in mango stems in response to ethephon sprays without an accompanying floral response. There was a clear relation between flowering and fruit yield per tree in both phases of the study with trees sprayed with $4 \% \mathrm{KNO}_{3}$ registering higher fruit yield in both sites. Relatively lower fruit number in Ethylene sprayed trees could be related to the higher fruit drop experienced by the trees as compared to the trees sprayed with $\mathrm{KNO}_{3}$ and the control. Higher concentrations $(1000 \mathrm{ppm})$ of ethephon resulted in better response for all the reproductive parameters measured. However, abscission of some leaves, flowers and immature fruits accompanied this high concentration of ethephon treatment. This problem can be resolved by applying ethephon at $600 \mathrm{ppm}$ rather than the higher dose of $1000 \mathrm{ppm}$ and also through timely application.

These findings show that ethephon and $\mathrm{KNO}_{3}$ can be explored as a strategy to induce an off-season flowering and fruiting. This is especially useful agro-ecological zones where flowering and fruiting in fruit trees such as mango occurs only once in a year. In this case flower initiation and flowering are dependent on an environmental signal which is often inconsistent. The chemicals can be used to substitute this natural phenomenon and realize a reasonable crop outside the peak season.

\section{Conclusion}

Spraying the 'Apple' and 'Ngowe' mango trees with $4 \% \mathrm{KNO}_{3}$ was found to be beneficial for all the flowering and fruiting parameters in both study sites. Ethephon can be sprayed at the rate of $600 \mathrm{ppm}$ rather than $1000 \mathrm{ppm}$ to minimize the negative effect of fruit drop on the trees. Moreover, in terms of the amount of Ethephon chemical used in application, it is more cost effective to spray Ethephon at $600 \mathrm{ppm}$ rather than $1000 \mathrm{ppm}$.

\section{Acknowledgements}

This research was funded by the Regional Universities Forum for Capacity Building in Agriculture (RUFORUM) through a grant (RU/2012/GRG-74) awarded to Dr. Jane Ambuko.

\section{References}

Abeles, F. B., Morgan, P. W., \& Saltveit, M. E. (1992). Ethylene in Plant Biology (2nd ed., p. 414). San Diego, CA: Academic.

Abeles, P. B. (1973). Ethylene in plant biology (pp. 153-196). Academia Press, New York. https://doi.org/ 10.1016/B978-0-12-041450-5.50013-4

Adam, C. S. (1986). Off-season flowering response of mango cultivars to potassium nitrate. Acta Horticulturae, 175, 277-280. https://doi.org/10.17660/ActaHortic.1986.175.40

Ambuko, L. J. (2016). The plight of smallholder mango farmers in Kenya during the pick season. HortFresh Journal 2016.

Barba, R. C. (1974). Induction of flowering of mango by chemical spray. Crop Sci. Soc. Philippines Proc., 5, 154-160. 
Bondad, N. D., \& Linsangan, E. (1979). Flowering in mango induced with potassium nitrate. Hort Science, 14, 527-528.

Bueno, P. B., \& Valmayor, R. V. (1974). Potassium nitrate: Key to mango flowering. Agric. California, $13,4$.

Chacko, E. K., Kohli, R. R., \& Randhawa, G. S. (1972). Studies on the effect of 2-chloroethylphosphonic acid (Ethrel) on mango, I. Flower induction in "off” year in Langra trees. Indian J. Horticulture, 29, 1-4.

Chacko, E. K., Kohli, R. R., \& Randhawa, G. S. (1974). Investigations on the use of 2-chloroethylphosphonic acid (Ethephon CEPA) for the control of biennial bearing in mango. Scientia Horticulturae, 2, 389-398. https://doi.org/10.1016/0304-4238(74)90045-4

Chanda, K. L., \& Pal, R. N. (1986). Mangifera indica. In A. C. Halevy (Ed.), CRC Handbook of Flowering 5 (pp. 211-30). CRC Press, Boca Raton, Florida, USA.

Davenport, T. L. (2003). Management of flowering in three tropical and subtropical fruit tree species. HortScience, 38, 1331-1335.

Davenport, T. L. (2009). Reproductive physiology. In R. E. Litz (Ed.), The Mango: Botany, Production and Uses (2nd ed., pp. 97-169). CAB International, Wallingford, UK. https://doi.org/10.1079/9781845934897.0097

Davenport, T. L., \& Núñez-Eliséa, R. (1990). Ethylene and other endogenous factors possibly involved in mango flowering. Acta Hort., 275, 441-448. https://doi.org/10.17660/ActaHortic.1990.275.54

Dutcher, R. D. (1972). Induction of early flowering in 'Carabao' mango in the Philippines by smudging and ethephon application. HortScience, 7, 343.

FAO. (2001). FAOSTAT 2001 database. Rome, Italy: Food and Agriculture Organization of the United Nations. http://apps.fao.org/default.htm

FAO. (2003). Value chain analysis: A case study of mangoes in Kenya. Rome, Italy: Food and Agriculture Organization of the United Nations.

Galan Elder, V., \& Fernandez Galvan, D. (1987). The culture of the handle in the Canary Islands. Notebooks of Disclosure 1/87. Ministry of Agriculture, Livestock and Fisheries, Government of the Canary Islands, Spain.

Goguey, T. (1992). Results obtained with three different flower inducing chemicals applied to the mangos 'Kent' and 'Zill'. IV International Mango Symposium, Miami, Florida.

Hamilton, R. A., Chia, C. L., \& Evans, D. O. (1992). Mango cultivars in Hawaii. Information Text Series 042. Hawaii Inst. Tropical Agriculture and Human Resources.

Huala, E., \& Susse, I. M. (1993). Determination and cell interactions in reproductive meristems. Plant Cell, 5, 1157-1165. https://doi.org/10.1105/tpc.5.10.1157

James, M., Lennox, D., \& Roberts-Nkrumah, L. (1992). The effect of potassium nitrate and boron treatments on mango (cv. Tommy Atkins) flowering and fruit retention. IV International Mango Symposium, Miami, Florida.

Kinet, J. M. (1993). Environmental, chemical, and genetic control of flowering. Hortic. Rev., 15, $279-334$. https://doi.org/10.1002/9780470650547.ch7

Kulkarni, V. J. (2004). The tri-factor hypothesis of flowering in mango. Acta Hort., 645, 61-70. https://doi.org/10.17660/ActaHortic.2004.645.3

Macias-Gonzales, J. L., Medina-Urrutia, V. M., \& Nunez-Elisea, R. (1992). Promotion of early flowering in mango with ammonium nitrate sprays as influenced by cultivar and shoot age. IV International Mango Symposium, Miami, Florida.

Madamba, J. E. (1978). The Philippines recommends for mango. Philippine Council for Agriculture and Resources Research.

Mosqueda-Vazquez, R., \& Avila-Resendiz, C. (1985). Floral induction of mango trees with applications of $\mathrm{KNO}_{3}$ and its inhibition to apply $\mathrm{AgNO}_{3}$ and $\mathrm{CoCl}_{2}$.

Nunez-Elisea, R. (1985). Flowering and fruit set of a monoembryonic and a polyembryonic mango as influenced by potassium nitrate sprays and shoots decapitation. Proc. Florida State Horticultural Soc., 98, 179-183.

Nunez-Elisea, R., Becerriland, A. E., \& Martinez Garza, A. (1980). The effect of ethrel on the flowering of mango cv. Haden. Chapingo, 23/24, 43-49. 
Ouma, L. A., Ambuko, J., Shibairo, S., \& Owino, W. O. (2014). Comparison of quality attributes of mango fruits produced from two contrasting agro-ecological zones of Kenya. Research Application Summary, $4^{\text {th }}$ RUFORUM Biennial Regional Conference July 21-25, Maputo, Mozambique.

Pal, R. N., Chadha, K. L., \& Rao, M. R. K. (1979). Effect of different plant growth regulators and other chemicals on flowering behavior of mango. Paper presented at Mango Workers Meeting held at Panji, Goa, May 2-5, 1979.

Sen, P. K., Bandopadhyay, M., Roy, S. S., \& Basu, R. N. (1973). Use of ethrel in controlling non-uniform bearing of mango. Indian Agric., 17, 185-288.

Sergent, E., Leal, F., \& Anez, M. (1996). Potassium thiosulphate, Urea and Potassium nitrate applications on vegetative and floral growth in mango 'Haden'. ISHS Acta Horticulturae 509: VI International Symposium on Mango.

Smith, J. D. (1994). Nitrogen fertilization of cranberries: What type should I use, how should I apply it, and where is my nitrogen from last season? Wisconsin Cranberry School Proceedings, 5, 23-30.

Stephenson, R. A., \& Gallagher, E. C. (1978). Effects of ethephon on macadamia racemes. Journal Horticultural Science, 62(4), 538-544.

Wilkie, J. D., Sedgley, M., \& Olesen, T. (2008). Regulation of floral initiation in horticultural trees. J. Exp. Bot., 59, 3215-3228. https://doi.org/10.1093/jxb/ern 188

Yeshitela, T., Robbertse, P. J., \& Stassen, P. J. C. (2004). Effects of various inductive periods and chemicals on flowering and vegetative growth of 'Tommy Atkins' and 'Keitt' mango (Mangifera indica) cultivars. New Zealand Journal of Crop and Horticultural Science, 32, 209-21. https://doi.org/10.1080/01140671.2004. 9514298

Yeshitela, T., Robbertse, P. J., \& Stassen, P. J. C. (2006). The impact of panicle and shoot pruning on inflorescence and developments in some mango cultivars. J. Appl. Hortic., 5, 69-75.

\section{Copyrights}

Copyright for this article is retained by the author(s), with first publication rights granted to the journal.

This is an open-access article distributed under the terms and conditions of the Creative Commons Attribution license (http://creativecommons.org/licenses/by/4.0/). 